\title{
Evaluation of the knowledge of pregnant women about the relationship between oral diseases and pregnancy complications
}

\author{
Avaliação do conhecimento das gestantes quanto à relação entre alterações \\ bucais e intercorrências gestacionais
}

\author{
Carmem Dolores de Sá CATÃO ${ }^{\text {a*}}$, Thaissa de Amorim GOMES ${ }^{\mathrm{b}}$, Rachel Queiroz Ferreira \\ RODRIGUES ${ }^{\mathrm{b}}$, Renata de Souza Coelho SOARES ${ }^{\mathrm{c}}$
}

\author{
${ }^{a}$ UFCG - Universidade Federal de Campina Grande, Campina Grande, PB, Brasil

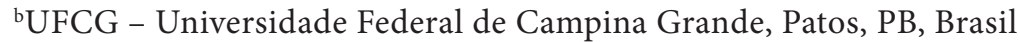 \\ 'UEPB - Universidade Estadual da Paraíba, Campina Grande, PB, Brasil
}

\begin{abstract}
Resumo
Introdução: Uma infecção crônica persistente de baixa intensidade na gestante, como a doença periodontal (DP), pode comprometer a unidade materno-fetal, já que o processo infeccioso induz a liberação de mediadores químicos envolvidos no processo de prematuridade. Objetivo: Avaliar o conhecimento das gestantes quanto à relação entre alterações bucais e intercorrências gestacionais. Método: Foi realizado um estudo epidemiológico de corte transversal, com 104 gestantes cadastradas no Sistema de Informação da Atenção Básica (SIAB), em Estratégias de Saúde da Família (ESF), empregando-se um questionário estruturado. Os dados foram registrados no SPSS e analisados por meio de estatística descritiva e inferencial, considerando-se um nível de significância de 5\%. Resultado: A maioria das gestantes $(64,4 \%)$ era doméstica, $(48,1 \%)$ com idade entre 24 a 34 anos, $(55,8 \%)$ apresentava o $2^{\circ}$ grau completo e incompleto e (49\%) era primípara. Dentre as participantes, $76 \%$ desconheciam a relação entre doença bucal, prematuridade e nascimento de bebês de baixo peso. Verificou-se associação estatisticamente significativa entre: escolaridade e o conhecimento sobre o pré-natal odontológico ( $\mathrm{p}=0,012)$, ao evidenciar que $90,4 \%$ ignoraram a existência desta atividade e $65,4 \%$ nunca haviam recebido informações sobre os cuidados de higiene bucal do bebê $(\mathrm{p}=0,003)$. Conclusão: A maioria das gestantes desconhecia a relação da DP com a prematuridade e apresentou carência de informações sobre os cuidados de higiene bucal materna e do bebê, evidenciando a necessidade de uma maior integração entre o Cirurgião-Dentista e os demais profissionais da atenção básica na propagação dos cuidados com a saúde bucal das gestantes para reduzir a relação da DP com as intercorrências gestacionais.
\end{abstract}

Descritores: Gravidez; periodontite; trabalho de parto prematuro; atenção primária à saúde.

\begin{abstract}
Introduction: Chronic persistent low-level infection in pregnant women, such as periodontal disease (PD) may impair maternal-fetal unit, since the infectious process induces the release of chemical mediators involved in the process of prematurity. Objective: To assess the knowledge of mothers as regards the relationship between oral diseases and pregnancy complications. Method: A cross-sectional epidemiological study was conducted with 104 pregnant women indexed in the Primary Care Information System (SIAB), in the Family Health Strategies (FHS), using a structured questionnaire. Data were recorded in SPSS and analyzed using descriptive and inferential statistics, considering a significance level of 5\%. Result: Most patients (64.4\%) were domestic workers, (48.1\%) aged 24 to 34 years, $\mathbf{( 5 5 . 8 \% )}$ ) showed complete the 2 nd grade and incomplete high school education, and (49\%) were primiparous. Among the participants, $76 \%$ were unaware of the relationship between oral disease, prematurity and giving birth to low birth weight babies. Statistically significant association was found between: educational level and knowledge about prenatal dental care $(\mathrm{p}=0.012)$; since it was shown that $90.4 \%$ ignored the existence of this activity and $65.4 \%$ had never received information about the care of baby's oral hygiene $(p=0.003)$. Conclusion: Most women were unaware of the relationship of PD with prematurity, and showed lack of information about the care of mother and baby oral hygiene, highlighting the need for greater integration between the dental surgeon and other primary care professionals to promote oral health care of pregnant women and reduce the ratio of PD with pregnancy complications.
\end{abstract}

Descriptors: Pregnancy; periodontitis; obstetric labor, premature; primary health care. 


\section{INTRODUCTION}

During the gestational period, the mother's body undergoes complex physiological, functional and anatomic changes, about which the dentist needs to know, in order to be able to correctly guide the pregnant woman with regard to her general state of health ${ }^{1}$.

There are cases in which the body is not in a state of homeostasis throughout gestation, and together with environmental and genetic conditions, this may result in premature births, and consequently babies with low birth weight ${ }^{2}$.

According to the World Health Organization (WHO) ${ }^{3}$, premature birth is defined as that which occurs between the 22nd and 37 th week of gestation and low birth weight, signifies babies born weighing less than $2,500 \mathrm{~g}$.

Innumerable risk factors during pregnancy may be associated with prematurity, with infections of the genitourinary regions being the main causes of pregnancy complications, however, infections sites in other parts of the body must not be overlooked ${ }^{4}$.

As a result of the hormonal alterations for the maintenance of pregnancy occurring in the mother's body, oral alterations may occur in pregnant women, due to the increase in peripheral vascularization and vascular permeability of gingival tissues. These stimulate the inflammatory process, and explain the increased incidence of gingivitis during the gestational period ${ }^{5}$.

The increased estrogen and progesterone levels in the blood have a repercussion on oral physiology, and act as factors for the growth of bacteria such as Prevotella intermédia. This may aggravate pre-existent periodontal diseases, particularly if the pregnant woman has neglected oral hygiene, because dental biofilm is of fundamental importance for the development of gingival inflammation ${ }^{6}$.

Periodontal disease is a bacterial infection that results from the interaction between periodontal tissues and dental biofilm. Studies have demonstrated that not only does the infected periodontium lead to oral alterations (gingivitis and periodontitis) but may also interact with the body, leading to systemic diseases during gestation. This occurs because the inflammatory mediators produced arrive at the placenta through the blood stream, and in some cases, may pass through the chorioamniotic barrier, and induce early uterine contractions ${ }^{7}$.

Gingival diseases are not caused by pregnancy ${ }^{8}$, but the increase in hormone levels interferes in the woman's oral health, changing the clinical condition of pre-existent oral alterations by producing a higher level of bleeding and erythema?

Pregnant women require greater dental care, however, there is a lack of multidisciplinary programs directed towards their oral health, with the aim of minimizing the potentiating effects of hormone alterations during pregnancy on their periodontal condition by providing oral hygiene instruction and periodontal treatment during the prenatal program ${ }^{10,11}$.

In view of the foregoing, the aims of this study were a) to evaluate the knowledge of pregnant women cared for in the Family Health Strategy (FHS) clinics of the municipality of Patos-PB, with regard to the relationship between oral health and pregnancy complications; b) to emphasize the importance or motivating this population group with regard to receiving prenatal dental care, with the goal of guaranteeing a healthy pregnancy without risks to the mother-fetus.

\section{METHOD}

A cross sectional epidemiological research was conducted with a quantitative approach to data, in the Family Health Strategy (FHS) clinics of a municipality in the interior of the Brazilian Northeastern region. The research universe consisted of pregnant women registered in the Basic Care Information System (SIAB) of the Family Health Strategy/SUS* of the Municipality of PatosPB ( ${ }^{*}$ SUS - Brazilian National Health service). According to the data provided by the municipal Secretary of Health, based on information of SIAB, there were 690 pregnant women registered in November 2013.

The sample calculation by extraction was determined by means of the Statistical software program BioEstat 5.0 (Belém, Pará, Brazil), with a interval of confidence of $95 \%$ and $10 \%$ margin of error. By this calculation, a sample of 138 participants to be considered for the research was determined, corresponding to $20 \%$ of the population.

As the sample was obtained in a non probabilistic manner, by convenience, in which the participants were selected according to their presence in the FHSs, at the time in which the research was being conducted, 104 pregnant women were recruited, and due to the impossibility of applying the questionnaire and/or incomplete information obtained, there was a loss of $25 \%$ of the total sample.

Included in the study were pregnant women in the agerange 13-40 years, in any period of gestation, whether they were primiparous (1st gestation), or not, registered in SIAB/SUS of the municipality researched. The women who did not meet with the above-mentioned prerequisites, and those who refused to participate in the study, by not signing the Term of Free and Informed Consent, were excluded from the study.

The Study was approved by the Ethics Committee on Research with Human Beings of the "Hospital Universitário Alcides Carneiro" (HUAC/UFCG) in Report No. 701.481.

Data were collected by means of a structured, self-applied questionnaire, previously prepared and based on the instrument used by Vieira, Zocrato ${ }^{10}$. This questionnaire contained information about the participants' socioeconomic data (age, educational level, occupation, marital status); data about oral hygiene (number of times of tooth brushing daily, and use of dental floss). With the aim of characterizing the care and prevention of periodontal disease in pregnant women, questions were prepared related to care by a multiprofessional team at the FHS; referral for dental treatment; pregnant women's' perception about the bidirectional relations between oral alterations (periodontal disease) and adverse pregnancy outcomes (prematurity and giving birth to babies with low birth weight) and dental care during pregnancy.

Data processing, storage and analysis were performed with the statistical software program SPSS 18.0 (Statistical Package for the 
Social Sciences) (SPSS Inc., Chicago, Illinois, USA), and analyzed by descriptive, as well as uni- and bivariate inferential statistics. The descriptive procedures were analyzed by means of absolute and relative data (frequencies and percentages). Inferential analyses, in turn, were performed by the Chi-square test, which identified the predominant response chosen by participants, and the associations between the qualitative variables. It is pointed out that the statistical tests were chosen in view of the nature of the variables (qualitative), and for interpretation of the information, the interval of confidence (IC) of $95 \%$ and level of significance of $5 \%(\mathrm{p}<0.05)$ were adopted.

\section{RESULT}

The final sample was composed of 104 pregnant women. During data collection, the number of losses was 34 participants (25\%), due to the impossibility of applying the questionnaire and/ or incomplete information provided. There was a predominance of pregnant women in the age-range between 24 and 34 years; with $(55.8 \%)$ presenting $2^{\circ}$ grade completed and incomplete, and (64.4\%) whose occupation was that of being a housewife and/ or domestic worker.

As regards their gestational experience (49\%) were primiparous, (36.5\%) were experiencing their second pregnancy, (12.5\%) their third, and only (1.9\%) their fourth or more pregnancies. With respect to knowledge about the relations between oral alterations and adverse pregnancy outcomes (57.7\%) responded that oral diseases could harm the pregnancyand (26.9\%) reported no, or that they did not know (15.4\%). The pregnant women agreed that gestation could cause oral problems: (9.6\%) mentioned toothache, (7.7\%) gingival bleeding, and (5.8\%) dental caries.

Among the interviewees, (61.5\%) responded that maternal oral alterations could harm the baby's health, while (30.8\%) responded no and (7.7\%) did not know.

According to occupation, only (24.04\%) of the pregnant women reported that maternal oral disease could cause the birth of babies with low birth weight and prematurity, $(\mathrm{p}=0.064)$ (Table 1). Whereas, significant associations were identified with the occupation of these pregnant women, and the opinion with regard to the type of oral disease that could contribute to pregnancy complications, showing that the majority (84.4\%) related these to gingival diseases (Table 2).

When correlating pregnant women's educational level with knowledge about bidirectional relations between maternal oral health an birth of babies with low birth weight and prematurity, no statistically significant relationship was observed.

With regard to oral hygiene habits and frequency of tooth brushing $(70.2 \%)$ of pregnant women said they brushed their teeth three times a day, (15.4\%) brushed four or more times, (12.5\%) twice a day (1.9\%) once a day. Among the pregnant women, (83.7\%) reported they used other auxiliary oral hygiene methods, such as dental floss.

Table 1. Percentage of pregnant women according to occupation and opinion about whether maternal oral disease could cause birth of babies with low birth weight and prematurity (Patos-PB, Brazil, 2014)

\begin{tabular}{|c|c|c|c|c|c|}
\hline \multirow[t]{2}{*}{ Occupation } & & \multicolumn{3}{|c|}{$\begin{array}{l}\text { Could maternal oral disease cause birth of babies with } \\
\text { low weight and prematurity? }\end{array}$} & \multirow[t]{2}{*}{ Total } \\
\hline & & Yes & No & Don' know & \\
\hline \multirow{2}{*}{ Domestic worker } & Frequency & 21 & 28 & 18 & 67 \\
\hline & $\%$ & $20.19 \%$ & $26.92 \%$ & $17.31 \%$ & $64.42 \%$ \\
\hline \multirow{2}{*}{ Others Professional Activities } & Frequency & 4 & 20 & 13 & 37 \\
\hline & $\%$ & $3.85 \%$ & $19.23 \%$ & $12.50 \%$ & $35.58 \%$ \\
\hline Significance & & \multicolumn{4}{|c|}{$\mathrm{p} 1=0.064$} \\
\hline
\end{tabular}

${ }^{1}$ Chi-Square Test, assuming the null hypothesis (H0).

Table 2. Percentage of pregnant women according to occupation and opinion about whether maternal oral disease could cause birth of babies with low birth weight and prematurity (Patos-PB, Brazil, 2014)

\begin{tabular}{|c|c|c|c|c|}
\hline \multicolumn{2}{|c|}{ Occupation } & \multicolumn{2}{|c|}{$\begin{array}{l}\text { Could maternal oral disease cause birth of babies } \\
\text { with low weight and prematurity? }\end{array}$} & \multirow[t]{2}{*}{ Total } \\
\hline & & Caries & Gingival Diseases & \\
\hline \multirow{2}{*}{ Domestic worker } & Frequency & 2 & 19 & 21 \\
\hline & $\%$ & $13.33 \%$ & $76 \%$ & $84 \%$ \\
\hline \multirow{2}{*}{$\begin{array}{c}\text { Others } \\
\text { Professional Activities }\end{array}$} & Frequency & 2 & 2 & 4 \\
\hline & $\%$ & $8 \%$ & $8 \%$ & $16 \%$ \\
\hline Significance & & & $\mathrm{p} 1=0.043$ & \\
\hline
\end{tabular}

${ }^{1}$ Chi-Square Test, assuming the null hypothesis (H0). 
When asked about seeking dental care/reason for seeking dental care during gestation, it was found that only $33.7 \%$ of the pregnant women sought care, and of these (16.3\%) went to the dentist for the purpose of prevention. Concerning dental care during pregnancy, the data obtained in this research revealed that (43.3\%) of the pregnant women never received information about oral health care, while $(56.7 \%)$ received instructions. Of these, (22.1\%) were instructed by the dentist, $(12.5 \%)$ by the nurse, (1\%) by the doctor, and $(21,2 \%)$ by other persons.

As regards guidance about oral health care of the baby, (65.4\%) did not receive any type of guidance, and of the $(34.6 \%)$ who received instructions, (14.4\%) received this information from other persons and not from the basic care professionals.

When being asked whether they had received guidance about the baby's oral care, this result was shown to be statistically significant $(\mathrm{p}=0.003)$, showing evidence of a higher percentage of pregnant women who never received this guidance (65.4\%) (Table 3).

With regard to knowledge about prenatal dental care, (90.4\%) of the pregnant women did not know about it and (9.6\%) had heard of it. With respect to the participants' educational level and knowledge about prenatal dental care, a statistically significant difference was observed ( $\mathrm{p}=0.012$ ), since only $9.6 \%$ of the pregnant women reported knowing of the existence of this activity, whereas $90.4 \%$ said that they had never hear anyone speaking about prenatal dental care; of these participants $39.42 \%$ had 1 st grade, $46.15 \%$ had 2 nd grade and $4.81 \%$ had higher learning educational levels (Table 4 )

\section{DISCUSSION}

It is important to elucidate factors that contribute to the appearance of pregnancy complications, because they could lead to prematurity and birth of babies with low birth weight ${ }^{12}$.

Periodontopathic bacteria or their toxins, present in periodontal infection, may migrate via the hematogenous system and reach the uterine cavity. They stimulate the elevated production of inflammatory mediators such as prostaglandins (PGE-2) and tumor necrosis factors $\alpha$ (FNT $\alpha$ ) by the pregnant women, generating cervical dilation, uterine contraction, infection of the chorion and maternal decidua which may afterwards lead to the onset of labor ${ }^{13}$.

Table 3. Percentage of pregnant women who received guidance about the baby's oral care, according to the number of pregnancies (Patos-PB, Brazil, 2014)

\begin{tabular}{|c|c|c|c|c|c|}
\hline & & & \multicolumn{2}{|c|}{$\begin{array}{l}\text { Did you receive guidance about the baby' } \\
\text { oral care? }\end{array}$} & \multirow{2}{*}{ Total } \\
\hline & & & Yes & No & \\
\hline \multirow{6}{*}{ Current pregnancy } & \multirow{2}{*}{ First } & Frequency & 11 & 40 & 51 \\
\hline & & $\%$ & $10.58 \%$ & $38.46 \%$ & $49.04 \%$ \\
\hline & \multirow{2}{*}{ Second } & Frequency & 16 & 22 & 38 \\
\hline & & $\%$ & $15.38 \%$ & $21.16 \%$ & $36.54 \%$ \\
\hline & \multirow{2}{*}{ Third or more } & Frequency & 9 & 6 & 15 \\
\hline & & $\%$ & $8.65 \%$ & $5.77 \%$ & $14.42 \%$ \\
\hline Significance & & \multicolumn{4}{|c|}{$\mathrm{p} 1=0.003$} \\
\hline
\end{tabular}

${ }^{1}$ Linear Chi-Square Test.

Table 4. Percentage of pregnant women who had knowledge about the existence prenatal dental case, according the educational level (Patos-PB, Brazil, 2014)

\begin{tabular}{|c|c|c|c|c|c|}
\hline & & & \multicolumn{2}{|c|}{$\begin{array}{c}\text { Knowledge about the existence of prenatal } \\
\text { dental care }\end{array}$} & \multirow{2}{*}{ Total } \\
\hline & & & Yes & No & \\
\hline \multirow{6}{*}{ Education } & \multirow{2}{*}{1 st grade } & Frequency & 0 & 41 & 41 \\
\hline & & $\%$ & $0 \%$ & $39.42 \%$ & $39.42 \%$ \\
\hline & \multirow{2}{*}{ 2nd grade } & Frequency & 10 & 48 & 58 \\
\hline & & $\%$ & $9.62 \%$ & $46.15 \%$ & $55.77 \%$ \\
\hline & \multirow{2}{*}{ Higher education. } & Frequency & 0 & 5 & 5 \\
\hline & & $\%$ & $0 \%$ & $4.81 \%$ & $4.81 \%$ \\
\hline Significance & & \multicolumn{4}{|c|}{$\mathrm{p} 1=0.012$} \\
\hline
\end{tabular}


The importance of dental care in the population group is, therefore, emphasized. In addition these women must have access to information with reference to their oral health and its relationship with pregnancy complications.

According to the socio-demographic data of the research, predominance was observed of pregnant women in the age-range between 24 and 34 years; complete and incomplete 2 nd grade, as educational level, and housewives and/ or domestic workers, as occupation. These results corroborate the findings of Cabral et al. ${ }^{14}$, in whose study the pregnant women participants of the interview were in the age-range from 17-37 years, the majority had complete 2nd grade educational level $(39.0 \%)$ and as regards their main occupation, $46.3 \%$ of them were performing domestic tasks.

With reference to gestational experience, the majority of them were experiencing their first pregnancy, in agreement with the studies of Bastiani et al. ${ }^{15}$, in which $48.75 \%$ of the pregnant women were primiparous. Primiparous mothers are receptive to information that will have positive results for their baby's health, and is thus an important characteristic of the sample.

According to the results of this study, among the participants that related pregnancy to oral problems, the majority mentioned that pregnancy caused toothache, and according to their educational level, there was no statistically significant difference. Vieira, Zocratto ${ }^{10}$ verified that popular belief that pregnancy causes caries is taken as the truth by (59.2\%) of the pregnant women interviewed, and this belief was not significantly associated with ( $p>0.05$ ) the socioeconomic or educational level of these women.

The majority of the interviewees responded that maternal oral health could harm the baby's health, while Bastiani et al. ${ }^{15}$ observed that only $26.25 \%$ of the pregnant women believed that alterations in their oral cavity, gingivitis or dental caries could influence the baby's general health.

With reference to the question about whether oral diseases could cause the birth of premature and low birth weight babies, a large portion of the interviewees answered no, however of the pregnant women who answered yes, the majority related this to gingival diseases.

In this study, no statistically significant difference was observed between the participants who expressed the opinion that maternal oral disease could cause the birth of low birth weight and premature babies, according to educational level. This showed evidence of the need for educational and health promotion programs related to the oral health of pregnant women, in order to transmit information about the relationship of periodontal disease with prematurity and birth of babies with low birth weight.

Studies have suggested that periodontal disease is associated with premature birth and low birth weight of babies ${ }^{16,17}$. However, other studies have pointed out the absence of these associations ${ }^{18,19}$.

Umoh et al. ${ }^{20}$ observed that there was association between maternal gingivitis and the outcome of pregnancy, however, further studies are necessary in the areas of microbiology, biochemistry of the subgingival flora and analysis of the maternal diet.

From the results, it was concluded that the number of pregnancies (first, second and third or more) did not influence the degree of knowledge of pregnant women with regard to the interrelationship or influence of periodontal disease on gestation, and vice-versa, since no statistically significant difference was shown. This showed evidence of the lack of dissemination of information about the subject, even when the pregnant women was multiparous.

The participants of this study presented satisfactory oral hygiene habits, since the majority brushed their teeth three times a day and used auxiliary oral hygiene methods, such as dental floss, corroborating the results found in studies by Catarin et al. ${ }^{21}$ and Monteiro et al. ${ }^{5}$, respectively. In these, $87,3 \%$ of the interviewees reported brushing their teeth three or more times a day and $82.6 \%$ of the pregnant women researched used dental floss, showing a good pattern of oral habits.

It was observed that the majority of pregnant women did not seek dental treatment during gestation. A similar result was found in a research conducted by Scavuzzi et al. ${ }^{11}$, both in the public and private sectors, the majority of pregnant women $(77.3 \%$ versus $74.6 \%)$ reported not having sought dental treatment during gestation. It is suggested that the absence of clinical manifestations leads to not seeking dental treatment, and that the quest for health is only active when pain and infection are present.

When asked by Amorim et al. ${ }^{22}$ the reason why they did not consult the dentist, they presented the following justifications: fear of the dentist, doing harm to the baby (32.6\%); they did not believe it was necessary (25.9\%); lack of time (17.4\%); indisposition and lack of care (6.6\%); treatment is very expensive (5.7\%); delay in being attended (31.9\%).

Dental monitoring is known to be important to prevent eventual repercussions of oral diseases on one's health as a whole.

The data obtained in this study revealed that the majority of pregnant women received some guidance about oral health. These results differ from those found by Cabral et al. ${ }^{14}$, in which only $31.7 \%$ of the pregnant women researched received guidance on oral health, whereas $68.3 \%$ of them received no instruction whatever.

As regards guidance about the baby's oral health care, a large portion of the women received no type of instruction. In a study conducted by Amorim et al. ${ }^{22}$, it was verified that $70 \%$ of the pregnant women investigated responded that they had not received any instructions on how to care for their mouth and that of the baby during the prenatal period, and 30\% affirmed that they had received information. Of these $20 \%$ received instructions from the obstetricians, and $10 \%$ from their Dentists or by reading magazines and books related to the subject.

Evidence was shown that pregnant women who were in their third or more pregnancies, proportionally, received more information about the baby's oral care, when compared with the others, seeing that this result was shown to be statistically significant.

The majority of participants did not know about prenatal dental care, as was also related by Batistella et al. ${ }^{23}$, in whose study the majority of pregnant women interviewed (86.6\%) had never heard anyone speak about the subject.

For Konishi, Abreu and Lima ${ }^{24}$ the role of prenatal dental care is to make pregnant women aware and instruct them about oral problems, plaque control and care of the future baby. Soares et al. ${ }^{25}$ stated that inclusion of dental care for pregnant women cannot be dispensed with during the prenatal program. 
Based on the results obtained in this study, a lack of information related to the bidirectional relationship of oral alterations with pregnancy complications could be observed. Furthermore there was lack of basic knowledge for care of the baby's oral health, and the importance of maintenance of maternal oral health to prevent undesirable effects during pregnancy, such as the induction of premature birth. This shows the relevance of preventive and educational campaigns for raising the consciousness of pregnant women about the importance of integral and periodic multidisciplinary care by basic care professionals - Doctor, Dentist and Nurse - with the purpose of combating the risk factors for periodontal disease in pregnant women, improving their quality of life and guaranteeing the health of the mother and fetus.

\section{CONCLUSION}

The pregnant women showed a lack of knowledge about the relationship between oral diseases and pregnancy complications (birth of premature babies and those with low birth weight.) It was shown that health professionals do not routinely evaluate the oral condition, and do not refer pregnant women for preventive of dental treatment during the prenatal period. It is known that the presence of a focus of infection arising from periodontal disease, for example, may lead to severe implications during pregnancy. The transfer of basic knowledge of oral health to the entire prenatal team is therefore, of extreme importance, in order to provide uniform concepts about dental care during pregnancy. In addition it is important to share this knowledge with pregnant women, who are the main persons responsible for the maintenance of oral physiological equilibrium, by taking oral health-related care. Thus it will be possible to prevent prematurity and birth of babies with low birth weight, through the maintenance of periodontal health. After the work of health promotion, the pregnant women must practice the knowledge acquired, in order to guarantee the health of the mother and fetus.

\section{REFERENCES}

1. Alves RT, Ribeiro RA, Costa LRRS. Associação entre doença periodontal em gestantes e nascimentos prematuros e/ou de baixo peso: um estudo de revisão. HU Rev. 2007 Jan-Mar;33(1):29-36.

2. Michalowicz BS, Durand R. Maternal periodontal disease and spontaneous preterm birth. Periodontol 2000. 2007; 44(1):103-12. http:// dx.doi.org/10.1111/j.1600-0757.2006.00197.x. PMid:17474928

3. Organización Mundial de la Salud - OMS. La prevención de la morbilidad y de la mortalidad perinatales. Ginebra: OMS; 1972.

4. Passini Júnior R, Nomura ML, Politano GT. Doença periodontal e complicações obstétricas: há relação de risco? Rev Bras Ginecol Obstet. 2007 July;29(7):370-5. http://dx.doi.org/10.1590/S0100-72032007000700008.

5. Monteiro RM, Scherma AP, Aquino DR, Oliveira RV, Mariotto AH. Avaliação dos hábitos de higiene bucal de gestantes por trimestre de gestação. Braz J Periodontol. 2012 Dec;22(4):90-9.

6. Mascarenhas P, Gapski R, Al-Shammari K, Wang HL. Influence of sex hormones on the periodontium. J Clin Periodontol. 2003 Aug;30(8):671-81. http://dx.doi.org/10.1034/j.1600-051X.2003.00055.x. PMid:12887335

7. Trentin MS, Scortegagna SA, Dal'Bello MS, Bittencourt ME, Linden MSS, Viero R, et al. Doença periodontal em gestantes e fatores de risco para o parto prematuro. RFO. 2007 Jan-Apr;12(1):47-51.

8. Newman MG, Takei HH, Klokkevold PR, Carranza FA. Periodontia clínica. 10. ed. Rio de Janeiro: Guanabara Koogan; 2007.

9. Sartorio ML, Machado WAS. A doença periodontal na gravidez. Rev Bras Odontol. 2001 Sept-Oct; 58(5):306-8.

10. Vieira GF, Zocratto KBF. Percepção das gestantes quanto a sua saúde bucal. Rev Flum Odontol. 2007 May-Aug;12(2):27-31.

11. Scavuzzi AIF, Nogueira PM, Laporte ME, Castro Alves A. Avaliação dos conhecimentos e práticas em saúde bucal de gestantes atendidas no setor público e privado, em Feira de Santana, Bahia, Brasil. Pesqui Bras Odontopediatria Clín Integr. 2008 Jan-Apr;8(1):39-45. http:// dx.doi.org/10.4034/1519.0501.2008.0081.0008.

12. Camata BC, Macedo AF, Duarte DA. O impacto do processo saúde-doença periodontal em gestantes em relação ao parto prematuro. RGO - Rev Gaúcha Odontol. 2007 July-Sept;55(3):267-70.

13. Naves RC, Novaes VM, Sadigursky LM, Viana AMV. Doença periodontal em mães com parto prematuro/recém-nascidos com baixo peso: estudo piloto. Innov Implant J Biomater Esthet (Impr). 2009 Sept; 4(3):40-5.

14. Cabral MCB, Santos TS, Moreira TP. Percepção das gestantes do Programa de Saúde da Família em relação à saúde bucal no município de Ribeirópolis, Sergipe, Brasil. Rev Port Saude Publica. 2013 July-Dec;31(2):173-80. http://dx.doi.org/10.1016/j.rpsp.2013.05.004.

15. Bastiani C, Cota ALS, Provenzano MGA, Fracasso MLC, Honório HM, Rios D. Conhecimento das gestantes sobre alterações bucais e tratamento odontológico durante a gravidez. Odontol Clín-Cient. 2010 Apr-June;9(2):155-60.

16. Nabet C, Lelong N, Colombier ML, Sixou M, Musset AM, Goffinet F, et al. Maternal periodontitis and the causes of preterm birth: the casecontrol Epipap study. J Clin Periodontol. 2010 Jan;37(1):37-45. http://dx.doi.org/10.1111/j.1600-051X.2009.01503.x. PMid:20096065

17. Resende M, Pinto E, Pinto M, Montenegro N. Doença periodontal, tabaco e parto pré-termo. Acta Med Port. 2011 Dec;24(Suppl 2):419-30. PMid:22849931.

18. Calabrese N, Calabrese A, Nibali L, Rosati A, Fiengo S, Di Renzo GC. Is there any association between periodontitis and preterm low birth weight? J Matern Fetal Neonatal Med. 2010 Nov;23(11):1288-93. http://dx.doi.org/10.3109/14767051003615467. PMid:20923276 
19. Vasconcelos JDAL, Santos ACC, Batista ALA, Granville-Garcia AF, Santiago LM, Menezes VA. Fatores de risco relacionados à prematuridade ao nascer: um estudo caso-controle. Odonto. 2012; 20(40):119-27.

20. Umoh AO, Savage KO, Ojehanon PI. Association between maternal gingivitis, low birth weight and preterm delivery. JMBR: A Peer-review. J Biomed Sci. 2013 June;12(1):65-75.

21. Catarin RFZ, Andrade SM, Iwakura MLH. Conhecimentos, práticas e acesso a atenção à saúde bucal durante a gravidez. Espaç Saúde (Online). 2008 Dec;10(1):16-24.

22. Amorim BF, Costa JF, Costa EL. Percepção de primigestas adolescentes sobre saúde bucal. Rev Pesq Saúde. 2011 May-Aug;12(2):13-7.

23. Batistella FID, Imparato JCP, Raggio DP, Carvalho AS. Conhecimento das gestantes sobre saúde bucal na rede pública e em consultórios particulares. RGO - Rev Gaucha Odontol. 2006 Jan-Mar;54(1):67-73.

24. Konishi F, Abreu e Lima F. Odontologia intra-uterina: a construção da saúde bucal antes do nascimento. Rev Bras Odontol. 2002 Sept-Oct; 59(5):294-5.

25. Soares MRPS, Dias AM, Machado WC, Chaves MGAM, Chaves Filho DM. Pré-natal odontológico: a inclusão do cirurgião-dentista nas equipes de pré-natal. Rev Interdisciplin Estud Exp. 2009 Apr-June;1(2):53-7.

\section{CONFLICT OF INTEREST}

The authors declare no conflicts of interest.

\section{${ }^{*}$ CORRESPONDING AUTHOR}

Carmem Dolores de Sá Catão, Rua Felix Carolino Barbosa, 150, Apto. 904, Lauritzen, 58401-414 Campina Grande, PB, Brasil, e-mail: cataocarmem@gmail.com

Received: July 20, 2014 Accepted: September 8, 2014 